\title{
Quantitative Analysis of Wallowing in a Confined Bison Herd
}

\section{Viktor REINHARDT ${ }^{1}$}

Reinhardt V., 1985: Quantitative analysis of wallowing in a confined bison herd. Acta theriol., 30, 7: 149-156 [With 1 Table, 1 Fig. \& Plate II]

Wallowing was recorded in a confined plains bison herd which was accompanied by bulls all year round. The quantitative analysis led to the following conclusions: 1. Wallowing was contagious thus functioning as a group cohesive element by synchronizing the herd's activity rhythm. 2. Wallowing was strictly related to the time of shedding but showed no significant correlation with breeding activity. Females were wallowing as often as males. It was suggested that rolling on the ground helps to relieve itching skin irritations caused by the process of molting. Wallowing was therefore referred to as a sexindependent self-grooming behaviour. 3. No evidence was found of wallowing serving to rid insects. 4. Old, dominant animals were wallowing more frequently than younger, subordinates ones. Wallowing activity of subordinates was restricted by the priorities of high ranking opponents who often displaced them from wallows. 5. Unlike cattle, bison perform very little social licking but cattle do not wallow. It was hypothesized that bison are less associative than cattle because they perform more self-grooming instead of social grooming. 6 . The animals of the study herd were predictable partners to each other, dominance relationships were stable and vicious encounters never took place. It was argued that wallowing was not acting as a conflict behaviour with social-display function.

[Department of Veterinary Anatomy. University of Saskatchewan. Saskatoon, Sask., Canada S7N 0W0]

\section{INTRODUCTION}

Behavioural studies of bison are scarce and mainly of descriptive nature. Wallowing for instance is a very conspicuous activity and most authors have described it in detail but none of them provides substantial quantitative data; only Cabon-Raczyńska et al. (1983) give the percentage distribution of wallowing in calves, juveniles and adults. So far wallowing has been described in free-ranging animals and there seems to be general consensus in classifying this behaviour as ambivalent, functioning both as a comfort and/or threat gesture (McHugh, 1958; Lott, 1974; Sambraus, 1981; Krischke, 1984), McHugh (1958) and Lott (1974) underline its agonistic feature in rutting bulls.

The present investigation is part of a socio-ethological study of a captive bison herd which, contrary to free-ranging populations, was accompanied by sexually mature males all year round. To further evaluate wallowing behaviour, its frequency was determined and relationships with shedding, breeding, age, sex and dominance analysed.

${ }^{1}$ Present address: Primate Research Center. 1223 Capitol Court, Madison, WJ 53715, U.S.A. 


\section{METHODS}

\subsection{Animals and Observations}

A commercial plains bison herd (Bison bison bison) kept in a 40 ha enclosure on the banks of the North Saskatchewan River, Canada, was observed during a total of 120 hours between February 1983 and January 1984. Starting about two hours after sunrise, 2-hour recordings were made on 5 consecutive days each month. The herd comprised 13 to 25 animals of both sexes and different age classes. Six adult cows, one adult bull, one subadult bull and four yearlings remained in the herd throughout the study period. Behavioural recordings were made simultaneously of all herd members while keeping a distance of at least $5 \mathrm{~m}$ to the closest one. The animals showed no noticeable reactions to the observer's presence and they could easily be identified by individual characteristics in appearance and temperament. Due to poor pasture, supplemental food was distributed twice a day. The enclosure was located in a dry, wind-exposed area and was virtually free of mosquitoes and flies. It never rained on observation days and the ground was either dry (April-November) or covered with $5-20 \mathrm{~cm}$ of snow (February-March and December-January). The animals had access to a pond which was partly surrounded by mud. They were never seen wallowing there but only on dry locations.

\subsection{Behaviour Recorded, Operational Terms, Statistical Tests}

W a llowing. Rolling on the ground towards the top of the back. In only one of 264 cases did a yearling roll from one side, over the top of the back, to the other side. In both sexes wallowing was preceded by sniffing and pawing of the ground and occasionally by tearing the sod with the horns and rubbing the chin and neck on the edge of the wallow. Commonly, places were chosen that had already been used by others, and this led to the formation of wallows (Phot. 1, Plate II), eroded, pan-shaped depressions.

Wallowing bout. Performing at least two successive rolling movements. Wallowing activity was measured as the number of wallowing bouts observed per animal per 2-hour observation session and was assessed in yearlings (1-2 years old), subadults ( $2-3$ years old) and adults (older than 3 years). Calves (younger than 1 year) were not taken into consideration because wallowing was atypical for them (only two instances observed) and they were not yet shedding (Phot. 1).

Shedding (Phot. 1). Losing pieces of underwool. Shedding bison were often rubbing their rump and face on the wire and the poles of the fence.

Tended cow. A female that is persistently followed by a subadult or by the adult bull during at least two hours. Tending was part of the precopulatory behaviour (cf. McHugh, 1958; Lott, 1981) and breeding activity was measured as the number of tended cows present per 2-hour observation period.

Dominance rank. According to the number of herd mates each animal dominated, a dominance rank order was established for the period June-October when herd composition and dominance relationships were stable. Between two animals the dominant one consistently threatened, butted or chased the other, the subordinate partner withdrew.

Statistical data analysis was done using Spearman's rank test and the MannWhitney test. 


\section{RESULTS}

A total of 264 wallowing bouts were recorded. In $61 \%$ of cases they were performed by two or more animals in succession. Five situations were witnessed in which more than half of all herd members were wallowing within less than 30 minutes.

Wallowing occurred in only 8 months of the year with high activity in 6 , low activity in 2 months. The time of high activity coincided exactly with the period of shedding, ranging from April to September; activity was low in the preceding and following months, March and October (Fig. 1).

The bison were wallowing throughout the shedding period ( 6 months) but only during $63 \%$ of the breeding season (5 of 8 months, Fig. 1). Wallowing and breeding activity were not significantly correlated $\left(r_{s}=0.395, \mathrm{n}=12, p>0.1\right.$; Fig. 1$)$.

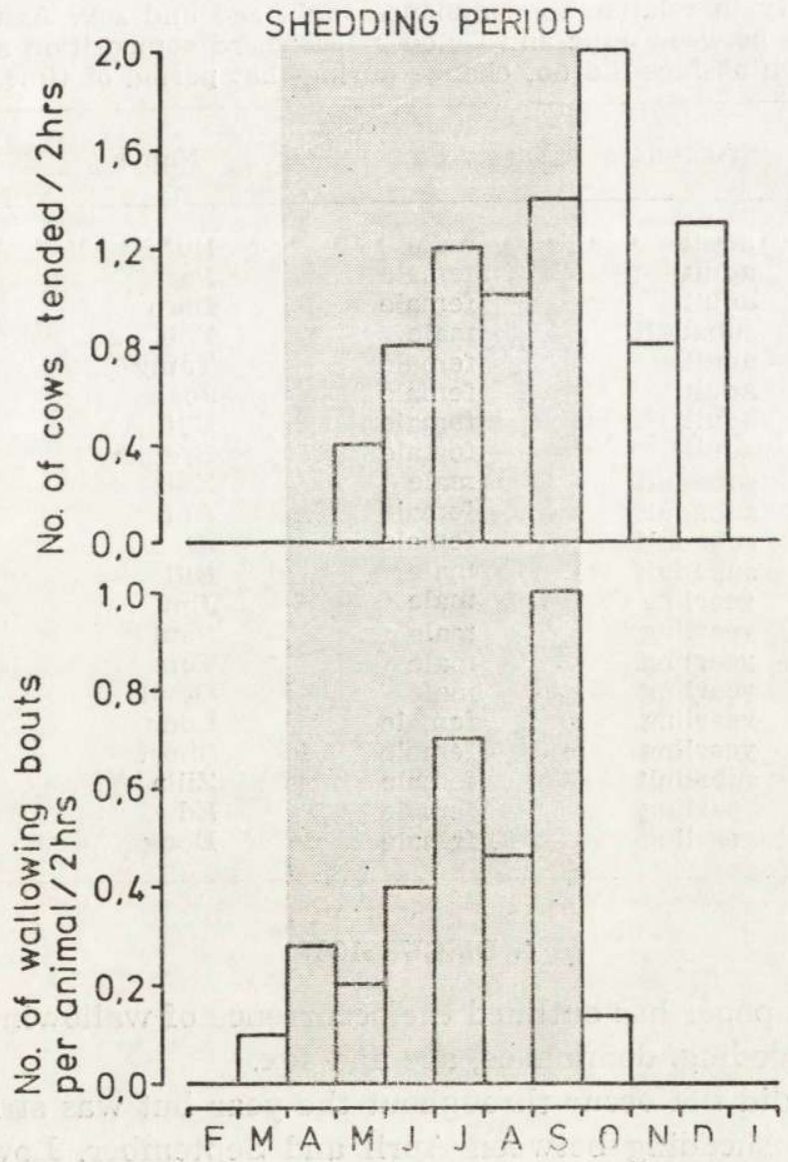

Fig. 1. Shedding and its relation to breeding and wallowing activity. 
Dominance rank strongly correlated with wallowing activity $\left(r_{s}=0.640\right.$, $\mathrm{n}=21, p<0.005$; Table 1). Dominance was also related to age, with older animals generally being superior to younger ones (Table 1). As a consequence of this, older animals were wallowing more frequently, the difference being significant between adults $(\bar{x}=27.1)$ and yearlings $(\bar{x}=7.2 ; p<0.025)$, between yearlings $(\bar{x}=7.2)$ and subadults $(\bar{x}=22.8$; $p<0.050)$, non-significant between adults $(\bar{x}=27.1)$ and subadults $(\bar{x}=22.8$, $p>0.1$; Table 1). Thirty-four situations were observed where an older, dominant animal displaced a younger, subordinate partner from a wallow, occupied the site and started wallowing.

The sexes did not differ either in dominance rank $\left(\bar{x}_{\text {male }}=10.5\right.$ vs $\bar{x}_{\text {female }}=11.3 ; p>0.1 ;$ Table 1$)$ or wallowing activity $\left(\bar{x}_{\text {male }}=14.4\right.$ bouts/ $50 \mathrm{hrs} v s \bar{x}_{\text {female }}=12.8$ bouts $/ 50 \mathrm{hrs}, p>0.1$; Table 1 ).

Table 1

Wallowing activity in relation to dominance rank, age and sex. Assessment based on data collected between June and October 1983; herd composition and dominance relationships did not change during that period of time.

\begin{tabular}{rlllr}
\hline $\begin{array}{c}\text { Dominance } \\
\text { rank position }\end{array}$ & Age-class & Sex & Name & $\begin{array}{r}\text { No. wallowing } \\
\text { bouts in } 50 \text { hrs }\end{array}$ \\
\hline 1 & adult & male & Bulli & 41 \\
2 & adult & female & Pat & 38 \\
3 & adult & female & Dora & 13 \\
4 & subadult & male & Bob & 19 \\
5 & adult & female & Tamy & 26 \\
6 & adult & female & Joan & 6 \\
7 & adult & female & Elli & 12 \\
8 & adult & female & Brenda & 9 \\
9 & subadult & male & Kan & 15 \\
10 & subadult & female & Ann & 13 \\
11 & subadult & female & Ci & 17 \\
12 & subadult & male & Bill & 5 \\
13 & yearling & male & Jim & 1 \\
14 & yearling & male & Paul & 10 \\
15 & yearling & male & Tom & 8 \\
16 & yearling & male & Devil & 16 \\
17 & yearling & female & Long & 4 \\
18 & yearling & female & Short & 14 \\
19 & subadult & female & Zilla & 1 \\
20 & yearling & female & Ed & 5 \\
21 & yearling & female & Doug & \\
\hline
\end{tabular}

\section{DISCUSSION}

The present paper has outlined the occurrence of wallowing in relation to shedding, breeding, dominance, age and sex.

Wallowing did not occur throughout the year but was strictly related to the time of shedding between April and September. Low wallowing 
activity was also noticed in March and October which may reflect the gradual, inapparent onset and termination of shedding. This inter relationship between shedding and wallowing suggests that rolling on the ground helps to relieve itching skin irritations caused by the process of molting. Characteristically, shedding was also associated with rubbing on the fence.

The animals were living in an area that was not infested by mosquitoes and flies which makes it unlikely that wallowing served to rid insects (Lott, 1974).

The relationship between wallowing and presence of tended cows was very weak indicating that wallowing performance was independent of breeding.

As already reported by Caboń-Raczyńska et al. (1983) older animals were wallowing more often than younger ones. Old animals, however, were also more dominant and they made use of their status by displacing young, subordinate herd mates from wallows. Apparently, they preferred rolling themselves in already formed, smooth depressions than on the flat, rough ground. Inevitably, this led to competition since the number of wallows was limited, each animal being reluctant to prepare a new one. Young, low ranking bison were wallowing relatively rarely, probably because their chances of using a wallow were restricted by the priorities of high ranking opponents.

Males and females did not differ in regard to wallowing activity but also not in terms of dominance rank. This shows that, unlike in African buffalo (Sinclair, 1977) wallowing in bison, is not a male prerogative.

The data of the present investigation lead to the conclusion that wallowing was a typical comfort behaviour. Its drive was not related to sex, its satisfaction however depended on dominance. Like social licking of cattle (Thiedemann, 1973) wallowing had a contagious effect. It thus functioned as a group cohesive element by contributing to the synchronization of the herd's activity rhythm.

Unlike cattle (Schloeth, 1961) bison perform very little social-licking (McHugh, 1958; Reinhardt, in press) but cattle do not wallow (Schloeth, 1961). It is possible that the wallowing of bison substitutes the licking of cattle and vice versa. Performing more self-grooming than socialgrooming, may explain why bison are less associative (Lott \& Minta, 1983) than cattle who facilitate and foster inter individual bonds by regularly licking each other (Reinhardt \& Reinhardt, 1981).

The present findings are not fully in line with the above mentioned concept which characterizes wallowing both as a grooming and threat gesture (McHugh, 1958; Lott, 1974). This concept is based on observations 
made in free-ranging bison where bulls viciously compete with each other over breeding priorities (Lott, 1976). It is feasible that such high-intensity aggressive encounters between unpredictable rivals may occasionally lead to a collision of the aggressive and of the fugitive drive in both contestants; wallowing being a non-agonistic activity may then function as a neutral, non-provocative display which suspends the imminent and critical decision - attacking or fleeing - for a short while.

Being forced to live together in one and the same exclusive group, bulls had become predictable to each other in the study herd. Firm dominance relationships were the guarantee of the top ranking bulls' unchallenged rights to tend cows (Reinhardt, in press; cf. McHugh, 1958; Cabon-Raczyńska et al., 1983). Dominance relationships were also stable among the other members of the herd which may be the reason why vicious encounters never took place (Reinhardt, in press) and opportunities for displacement wallowing (McHugh, 1958) thus not given.

Acknowledgements: I am indebted to Mr. Lyle Lamb who gave me permission to study his bison herd on Steel Rose Ranch. The manuscript benefitted from critical reading by $\mathrm{Dr}$. Joe $\mathrm{Schmutz}$ and by my wife Annie; their constructive comments are very much appreciated.

\section{REFERENCES}

1. Caboń-Raczyńska M., Krasińska M. \& Krasiński Z., 1983: Behaviour and daily activity rhythm of European bison in winter. Acta theriol., 28: 273-299.

2. Krischke N., 1984: Beiträge zum Sozialverhalten des Wisents (Bison bison bonasus L.). Z. Säugetierk., 49: 43-54.

3. Lott D. F., 1974: Sexual and aggressive behavior of adult male American bison (Bison bison). [In: "The behaviour of ungulates and its relation to management". Geist, V., Walther, F., eds.]. 1: 382-394. IUCN, Morges Switzerland.

4. Lott D. F., 1976: Sexual behavior of the American bison. (film) Psychol. Cin. Reg. Pennsylvania State Univ., PCR 2276.

5. Lott D. F., 1981: Sexual behavior and intersexual strategies in American bison. Z. Tierpsychol., 56: 97-114.

6. Lott D. F. \& Minta S. C., 1983: Random individual association and social group instability in American bison (Bison bison). Z. Tierpsychol., 61: 153-172.

7. McHugh T. S., 1958: Social behaviour of the American buffalo (Bison bison bison). Zoologica, 43: 1-40.

8. Reinhardt V. \& Reinhardt A., 1981: Cohesive relationships in a cattle herd. Behaviour, 77: 121-151.

9. Sambraus H. H., 1981: Verhalten, Zucht und Haltung des Bisons in Nordamerika. Z. Tierzüchtg. Züchtungsbiol., 98: 210-219.

10. Schloeth R., 1961: Das Sozialleben des Camargue Rindes. Z. Tierpsychol. 18: $574-627$.

11. Sinclair A. R. E., 1977: The African buffalo. A study of resource limitation of populations. The Univ, of Chicago Press, Chicago, Ill. 
12. Thiedemann D., 1973: Das Sozialverhalten von Jungmastbullen im Laufstall unter besonderer Berücksichtigung der sozialen Rangordnung. Schriftenreihe des Max-Planck-Instituts, Mariensee-Trenthorst, Heft 66.

Accepted, October 15, 1984.

Viktor REINHARDT

ANALIZA ILOSCIOWA TARZANIA SIE U BIZONÓW Z ZAMKNIĘTEGO STADA

\section{Streszczenie}

Obserwowano tarzanie się bizonów (Bison bison bison) w stadzie trzymanym w czterdziestohektarowej zagrodzie (Ryc. 1). Stado składało sié z 13 do 25 samców i samic, w różnym wieku. Analiza ilościowa doprowadziła do nastẹpujących wniosków: 1. Tarzanie się stanowiło element spajający grupę, gdyż występowało synchronicznie w całym stadzie. 2. Tarzanie się było ściśle uzależnione od czasu linienia, lecz nie wykazywało korelacji z aktywnością rozrodczą (Ryc. 2). Sugeruje to, że tarzanie się po ziemi przynosi ulgę swędzącej skórze podrażnionej linieniem. Było ono przeto przypisywane typowemu, niezależnemu od plci osobistemu behawiorowi „kosmetycznemu". 3. Nie stwierdzono aby tarzanie się pomagało w uwalnianiu się od insektów. 4. Dorosłe, dominujące zwierzęta tarzały się częściej niż młode, podporządkowane. Te ostatnie były wypędzane przez dominanty $z$ miejsc dogodnych do tarzania się. 5. Odmiennie niż u bydła, bizony bardzo rzadko liżą się wzajemnie, ale bydło się nie tarza. W związku z tym nasuwa się wniosek, że bizony są mniej asocjacyjne niż bydło, gdyż właściwszy im jest osobisty behawior „kosmetyczny”, niż taki behawior socjalny. 6. Partnerstwo w stadzie było ustalone a struktura dominacyjna nie ulegała zmianom. 


\section{EXPLANATION OF PLATE II}

Phot. 1. Cow Elli is rolling towards the top of her back in a wallow, an eroded pan-shaped depression. Note that all animals with the exception of Elli's calf are shedding. 
ACTA THERIOLOGICA, Vol, XXX, 7

Plate II

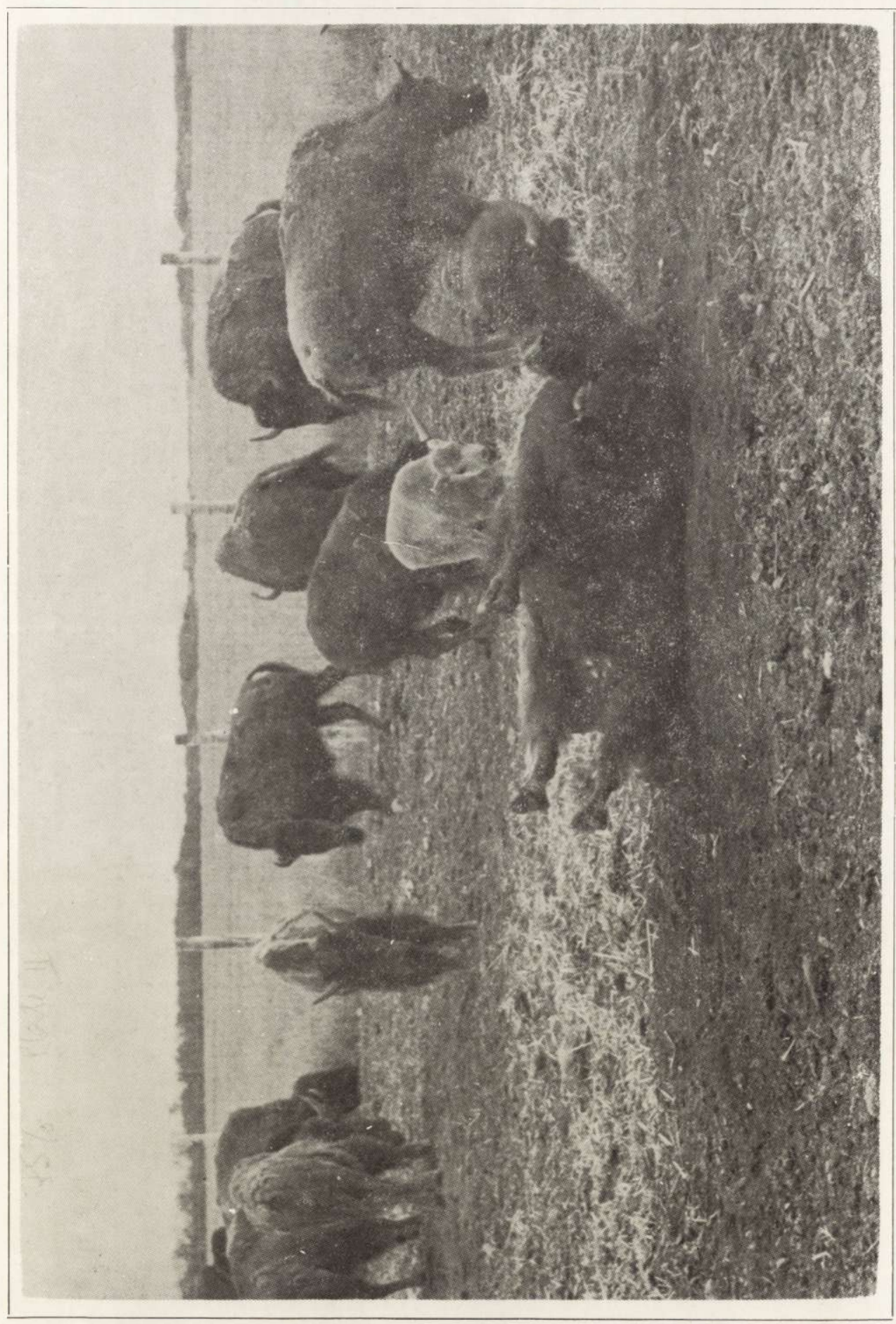

V. Reinihardt 